\title{
Differential pathogenicity of two different recombinant PVYNT isolates in Physalis floridana is likely determined by the coat protein gene
}

\author{
Xinxi $\mathrm{Hu}^{1}$, Xianzhou $\mathrm{Nie}^{2^{*}}$, Changzheng $\mathrm{He}^{1}$ and Xingyao Xiong ${ }^{1}$
}

\begin{abstract}
A previous study has identified two types of recombinant variants of Potato virus $Y$ strain NTN (PVY ${ }^{N T N}$ ) in China and sequenced the complete genome of the variant PVY ${ }^{N T N}-H N 2$. In this study, the complete genome of isolate PVY NTN_HN1 was fully sequenced and analyzed. The most striking difference between the two variants was the location of recombinant joint three (RJ3). In PVY ${ }^{\text {NTN }}-$ HN1, like other typical European-PVY ${ }^{\text {NTN }}$ isolates such as PVY NTN -Hun, the RJ3 was located at nucleotide (nt) 9183, namely the $3^{\prime}$ proximal end of the CP gene (nt. 85719371), thus leading to most (the first 613 nucleotides from the $5^{\prime}$ proximal end) of the CP gene (801 bp) with a $P V Y^{N}$ origin and PVY ${ }^{N}$-serotype; whereas in contrast, the RJ3 in PVY ${ }^{N T N}-H N 2$ was located at nt 8572, consequently leading to a $\mathrm{CP}$ gene of $\mathrm{PVY}^{\mathrm{O}}$ origin and $\mathrm{PVY}^{\mathrm{O}}$-serotype. The varied genome composition among $\mathrm{PVY}, \mathrm{PVY}^{\mathrm{N}}, \mathrm{PVY}^{\mathrm{N}}$ : ${ }^{\circ}$, PVY $^{\text {NTN }}{ }_{-H N 1}$ and PVY ${ }^{N T N}$-HN2 made them useful for the investigation of possible roles of gene segment(s) in symptom formation on host plants. When Physalis floridana plants were infected with different PVY isolates, two types of symptoms were induced. PVY and PVY ${ }^{N T N}{ }_{-H N}$ induced mild symptoms (mainly mild mottling) whereas $P V Y^{O}, P V Y^{N: O}$ and $P V Y^{N T N}-H N 2$ induced serve symptoms including leaf and stem necrosis, leaf-drop and stunting. These results, together with a previous study using artificial PVY chimeras, demonstrate that the CP gene, especially the $5^{\prime}$ proximal segment (nt 8572-9183), and/or CP likely determine the pathogenicity of PVY in P. floridana.
\end{abstract}

\section{Findings}

Potato virus $Y$ (PVY) is the type species of the Potyvirus genus in the Potyviridae family [1]. It infects a number of plant species in the nightshade family (Solanaceae) and causes a wide range of symptoms from symptomless to mosaic, mottling, lesions, stunting, necrosis and plant death, depending on the plant species, the cultivar, the virus strain and isolate [1]. PVY possesses a singlestranded positive RNA genome comprised of approximately 9700 nucleotides that encode a polyprotein of approximately 3061 amino acids [2]. The polyprotein undergoes proteolysis to form 10 mature proteins with different functions including replication, transportation and spread of the virus [1,2]. Many strains/substrains of PVY have been recognized according to the primary hosts and host reactions. For the potato-infecting PVY, the ordinary strain $\left(\mathrm{PVY}^{\mathrm{O}}\right)$, the tobacco veinal necrosis

\footnotetext{
* Correspondence: xianzhou.nie@agr.gc.ca

${ }^{2}$ Potato Research Centre, Agriculture and Agri-Food Canada, P.O. Box 20280,

850 Lincoln Road, Fredericton, New Brunswick, E3B 4Z7, Canada

Full list of author information is available at the end of the article
}

strain $\left(\mathrm{PVY}^{\mathrm{N}}\right)$ and the potato stipple streak strain $\left(\mathrm{PVY}^{\mathrm{C}}\right)$ are the first ones to be recognized [1], followed by the potato tuber necrosis strain $\left(\mathrm{PVY}^{\mathrm{NTN}}\right)$ and the recombinant $\mathrm{N}: \mathrm{O} / \mathrm{Wilga}$ group $\left(\mathrm{PVY}^{\mathrm{N}: \mathrm{O}}\right.$ or $\mathrm{PVY}^{\mathrm{N}}$ Wilga) [3-5]. PVY ${ }^{\mathrm{NTN}}$ is characterized by its ability to induce potato tuber necrotic ringspot disease (PTNRD) in sensitive potato cultivars [5-7], whereas $\mathrm{PVY}^{\mathrm{N}: \mathrm{O}}$ is defined by its reaction to $\mathrm{PVY}^{\mathrm{O}}$-specific antibody (i.e., $\mathrm{PVY}^{\mathrm{O}}$-serotype) but causing veinal necrosis on tobacco plants (i.e., $\mathrm{PVY}^{\mathrm{N}}$ pathotype) $[5,8]$. Two types of $\mathrm{PVY}^{\mathrm{NTN}}$, one recombinant and the other non-recombinant, have been identified $[4,7,9]$. The former is represented by PVY ${ }^{\mathrm{NTN}}-$ Hun [10] and has been referred to as European (Eu)-PVY $Y^{\mathrm{NTN}}[7,11-13]$, and the latter is represented by $\mathrm{PVY}^{\mathrm{NTN}}-\mathrm{Tu} 660$ [7] and has been referred to as North American (NA)-PVY ${ }^{\mathrm{NTN}}$ $[7,11,12,14]$. Both Eu-PVY ${ }^{\mathrm{NTN}}$ and NA-PVY ${ }^{\mathrm{NTN}}$ react to $\mathrm{PVY}^{\mathrm{N}}$-specific antibody $[11,13]$. Recently, a new recombinant PVY ${ }^{\mathrm{NTN}}$ variant type has been identified in Syria $[15,16]$ and China [9]. The variant type that includes the isolates $\mathrm{PVY}^{\mathrm{NTN}-\mathrm{NW}}[16]$ and $\mathrm{PVY}^{\mathrm{NTN}}-\mathrm{HN} 2$ [9] reacts
C Biomed Central

(c) 2011 Hu et al; licensee BioMed Central Ltd. This is an Open Access article distributed under the terms of the Creative Commons Attribution License (http://creativecommons.org/licenses/by/2.0), which permits unrestricted use, distribution, and reproduction in any medium, provided the original work is properly cited. 
to $\mathrm{PVY}^{\mathrm{O}}$-antibody and induces veinal necrosis on tobacco and PTNRD on sensitive potato cultivars $[9,16]$. Reverse transcription-PCR (RT-PCR) based genotyping has been successfully used to characterize the genome features of the Eu-PVY ${ }^{\mathrm{NTN}}$-like isolate $\mathrm{PVY}^{\mathrm{NTN}}-\mathrm{HN} 1$ and the $\mathrm{PVY}^{\mathrm{NTN}-\mathrm{NW}}$-like isolate $\mathrm{PVY}^{\mathrm{NTN}}-\mathrm{HN} 2$ in China [9]. Here we report the differential responses of Physalis floridana to $\mathrm{PVY}^{\mathrm{NTN}}-\mathrm{HN} 1$ and $\mathrm{PVY}^{\mathrm{NTN}}-\mathrm{HN} 2$ infections. $\mathrm{PVY}^{\mathrm{NTN}}-\mathrm{HN} 1$ and $\mathrm{PVY}^{\mathrm{N}}$ induced mottling on P. floridana whereas $\mathrm{PVY}^{\mathrm{NTN}}-\mathrm{HN} 2, \mathrm{PVY}^{\mathrm{O}}$ and $\mathrm{PVY}^{\mathrm{N}: \mathrm{O}}$ induced severe symptoms including leaf and stem necrosis, leaf-drop and stunting. The results, together with the genome make-ups of various PVY isolates, suggest that the CP gene plays a significant role in symptom induction in P. floridana, consistent with the results reported by Bukovinszki et al. [17].

The greenhouse maintained PVY isolates PVY ${ }^{\mathrm{NTN}}$ HN1 (formerly PVY sample 1 [9]), PVY ${ }^{\mathrm{NTN}}-\mathrm{HN} 2$, $\mathrm{PVY}^{\mathrm{N}}$-Jg, $\mathrm{PVY} \mathrm{O}^{-\mathrm{RB}}$ and $\mathrm{PVY}^{\mathrm{N}: \mathrm{O}}-\mathrm{Mb} 58$ in 'Russet Burbank' plants/tubers $[5,7,9,11-13]$ were used in this study. $\mathrm{PVY}^{\mathrm{NTN}}-\mathrm{HN} 1$ and $\mathrm{PVY}^{\mathrm{NTN}}-\mathrm{HN} 2$ were obtained in China [9], while the rest were from Canada [5,7,11-13]. All isolates have been characterized molecularly by $\mathrm{P} 1$ gene- and recombinant joint (RJ)-based RT-PCR assays $[12,13]$, pathologically by tobacco- and potato-based bioassays, and serologically by $\mathrm{PVY}^{\mathrm{O}}$ - and $\mathrm{PVY}^{\mathrm{N}}$-antibody-based ELISA assays [5,7,9,11-13,18]. Moreover, except for $\mathrm{PVY}^{\mathrm{NTN}}-\mathrm{HN} 1$, all of the isolates have been sequenced fully $\left(\mathrm{PVY}^{\mathrm{NTN}}-\mathrm{HN}-2, \mathrm{PVY}^{\mathrm{N}}-\mathrm{Jg}, \mathrm{PVY}{ }^{\mathrm{O}}-\mathrm{RB}\right)$ or partially $\left(\mathrm{PVY}^{\mathrm{N}: \mathrm{O}}-\mathrm{Mb} 58\right)$ (accession numbers are HM367076, AY166867, GQ200836, AY745493 for $\mathrm{PVY}^{\mathrm{O}}-\mathrm{RB}, \mathrm{PVY}^{\mathrm{N}}-\mathrm{Jg}, \mathrm{PVY}^{\mathrm{NTN}}-\mathrm{HN}-2$, and $\mathrm{PVY}^{\mathrm{N}: \mathrm{O}}-\mathrm{Mb} 58$ respectively). To better understand the isolate $\mathrm{PVY}^{\mathrm{NTN}}$ $\mathrm{HN} 1$, especially to reveal the exact nucleotide locations of the recombinant joints that had been detected by RTPCR [9], the complete genome of PVY ${ }^{\mathrm{NTN}}-\mathrm{HN} 1$ was sequenced. The same nine sets of PCR primers (for primer sequences, see reference [7]) that had been used to clone/sequence various isolates of PVY $[5,7,9,18]$ were used. Each primer pair resulted in a DNA fragment of 1.0 to $1.3 \mathrm{~kb}$, overlapping with adjacent fragments with approximately $100 \mathrm{bp}$ at each end. Each fragment was cloned into a pGM-T cloning vector (TIANGEN Biotech, Beijing, China) according to the manufacturer's instructions; and two clones of each fragment were sequenced from both forward and reverse directions using the universal T7 promoter and SP6-promoter primers at the Sangon Biological Engineering Technology \& Services Co. Ltd (Shanghai, China). The complete genome sequence (GenBank accession number HQ631374) was confirmed by re-sequencing overlapping cDNA clones obtained from a separate experiment from RNA isolated from $\mathrm{PVY}^{\mathrm{NTN}}-\mathrm{HN} 1$ infected tobacco leaves. Sequence identities were analyzed using BLAST
(http://www.ncbi.nlm.nih.gov/BLAST). For detection of the recombinant events, complete nucleotide sequences of various PVY isolates were aligned using ClustalW2 (http://www.ebi.ac.uk/Tools/clustalw2/index.html) [19]. The aligned sequences served as inputs for similarity scanning using the program SimPlot [20, generously provided by the author at http://sray.med.som.jhmi.edu/]. The resulting similarities were plotted along the nucleotide sequences of the virus genome.

As anticipated, $\mathrm{PVY}^{\mathrm{NTN}}$-HN1 shared highest sequence identities with $\mathrm{PVY}^{\mathrm{NTN}}$-Hun, a representative of typical $\mathrm{Eu}-\mathrm{PVY} \mathrm{NTN}^{\mathrm{N}}$, at both complete nucleotide and polyprotein levels at $99.2 \%$ and $99.1 \%$, respectively. It was followed by $\mathrm{PVY}^{\mathrm{NTN}}-\mathrm{HN} 2 / \mathrm{PVY}^{\mathrm{NTN}-\mathrm{NW}}, \mathrm{PVY}^{\mathrm{N}: \mathrm{O}}, \mathrm{PVY}^{\mathrm{N}}$ and $\mathrm{PVY}^{\mathrm{O}}$, represented by isolates $\mathrm{PVY}^{\mathrm{NTN}}-\mathrm{HN} 2, \mathrm{PVY}^{\mathrm{N}}$ : ${ }^{\mathrm{O}}-\mathrm{Mb} 112, \mathrm{PVY}^{\mathrm{N}}-\mathrm{N} 605$ and $\mathrm{PVY}{ }^{\mathrm{O}}-\mathrm{RB}$, respectively (Table 1). The sequence identities between $\mathrm{PVY}^{\mathrm{NTN}}$ HN1 and $\mathrm{PVY}^{\mathrm{N}}-\mathrm{Jg}$, a NA- PVY ${ }^{\mathrm{N}}[7,11]$, were $90.9 \%$ and 95.9\% at the complete nucleotide and polyprotein levels, respectively (Table 1 ). As expected, the sequence identities between $\mathrm{PVY}^{\mathrm{NTN}}-\mathrm{HN} 1$ and $\mathrm{PVY}^{\mathrm{N}: \mathrm{O}}-\mathrm{Mb} 58$ (accession number AY745493, partial length) were similar to that between $\mathrm{PVY}^{\mathrm{NTN}}-\mathrm{HN} 1$ and $\mathrm{PVY}^{\mathrm{N}: \mathrm{O}}-\mathrm{Mb} 112$ (data not shown). Further comparison of $\mathrm{PVY}^{\mathrm{NTN}}-\mathrm{HN} 1$ with $\mathrm{PVY}^{\mathrm{NTN}}-\mathrm{HN} 2$ at mature protein level revealed that the two shared high sequence identities for all proteins $(97.8$ - 100\%) but the CP (Table 1), which was similar to that exhibited in $\mathrm{PVY}^{\mathrm{NTN}}-\mathrm{Hun}$ vs $\mathrm{PVY}^{\mathrm{NTN}}-\mathrm{HN} 2$ [9]. Sequence screening of $\mathrm{PVY}^{\mathrm{NTN}}-\mathrm{HN} 1$ against $\mathrm{PVY} \mathrm{O}^{\mathrm{O}}$ (e.g., $\mathrm{PVY}^{\mathrm{O}}-\mathrm{RB}$ ) and $\mathrm{PVY}^{\mathrm{N}}$ (e.g., $\mathrm{PVY}^{\mathrm{N}}-605$ or $\mathrm{PVY}^{\mathrm{N}}$-Jg) using SimPlot [20] revealed three recombinant joints at $\mathrm{nt}$ 2419, 5844 and 9183 in PVY ${ }^{\mathrm{NTN}}$-HN1 genome (Figure 1D), resulting from the genome recombination between $\mathrm{PVY}^{\mathrm{N}}$ and $\mathrm{PVY}^{\mathrm{O}}$. In contrast, the RJs in $\mathrm{PVY}^{\mathrm{NTN}}-\mathrm{HN} 2$ were located at nt 2521, 5867 and 8572 (Figure 1D) [9]. $\mathrm{PVY}^{\mathrm{NTN}}-\mathrm{HN} 1$ shares identical RJs with $\mathrm{PVY}^{\mathrm{NTN}}-\mathrm{Hun}$ (data not shown). The location of RJ3 in $\mathrm{PVY}^{\mathrm{NTN}}-\mathrm{HN} 1$ and $\mathrm{PVY}^{\mathrm{NTN}}$-Hun at nt 9183, namely the 3' proximal end of CP gene (nt 8571-9371), led to most (the first $613 \mathrm{nt}$ from the 5' proximal end) of the 801-bp-long CP gene of a $\mathrm{PVY}^{\mathrm{N}}$ origin, which eventually resulted in a $\mathrm{PVY}^{\mathrm{N}}$-serotype of these isolates $[5,7,9]$. In contrast, the RJ3 in PVY ${ }^{\mathrm{NTN}}$-HN2/PVY ${ }^{\mathrm{NTN}}$-SYR-NB-16N (accession number AB270705) at nt 8572, namely the 5'end of the $\mathrm{CP}$ gene, led to the complete $\mathrm{CP}$ gene of a $\mathrm{PVY}^{\mathrm{O}}$ origin, which further resulted in a $\mathrm{PVY}^{\mathrm{O}}$-serotype $[9,15]$. One RJ, namely RJ1, was present in $\mathrm{PVY}^{\mathrm{N}: \mathrm{O}}$ isolates including $\mathrm{PVY}^{\mathrm{N}: \mathrm{O}}-\mathrm{Mb} 112$ and $\mathrm{PVY}^{\mathrm{N}: \mathrm{O}}-\mathrm{Mb} 58$ at nt 2397 [5] (Figure $1 \mathrm{D})$, resulting in a recombinant genome in which the segment prior to the RJ was from $P V Y^{N}$ and the remainder from $\mathrm{PVY}^{\mathrm{O}}$ [5].

Previous study has revealed the pathotypes of $\mathrm{PVY}^{\mathrm{NTN}}-\mathrm{HN} 1$ and $\mathrm{PVY}^{\mathrm{NTN}}-\mathrm{HN} 2$ on tobacco and potato [9]. To further characterize the biological properties of 
Table 1 Identities between isolate PVY ${ }^{\text {NTN }}-$ HN1 and other isolates of Potato virus $Y$ (PVY) at both nucleic acid and protein levels

\begin{tabular}{|c|c|c|c|c|c|c|c|c|}
\hline & \multicolumn{2}{|l|}{ Length } & \multicolumn{6}{|c|}{ Sequence Identity (\%) (Nucleic acid, Protein) } \\
\hline & $\begin{array}{l}\text { Gene nucleotide, } \\
\text { size (bp) }\end{array}$ & $\begin{array}{l}\text { Protein } \\
\text { size (aa) }\end{array}$ & $\begin{array}{l}\text { PVY }-R B \\
\text { (HM367076) }\end{array}$ & $\begin{array}{l}P^{P V Y^{N}-605} \\
(X 97895)\end{array}$ & $\begin{array}{l}\text { PVY }- \text {-Jg } \\
\text { (AY166867) }\end{array}$ & $\begin{array}{l}\text { PVY }^{\text {NTN }} \text {-Hun } \\
\text { (M95491) }\end{array}$ & $\begin{array}{l}\text { PVYN:O-Mb112 } \\
\text { (AY745491) }\end{array}$ & $\begin{array}{l}\text { PVY }^{\text {NTN }} \text {-HN2 } \\
\text { (GQ200836) }\end{array}$ \\
\hline $5^{\prime}$ UTR & $1-188,188$ & - & $66.0,-$ & $100,-$ & $85.6,-$ & $100,-$ & $100,-$ & $99.5,-$ \\
\hline P1 & $189-1013,825$ & 275 & 73.0, 71.3 & $99.3,99.6$ & $92.2,91.3$ & $98.7,98.2$ & $99.6,100$ & $98.9,100$ \\
\hline HC-Pro & $1014-2408,1395$ & 465 & $82.2,90.5$ & $98.8,99.4$ & $92.6,96.8$ & $99.1,99.1$ & $98.4,99.4$ & $98.4,98.9$ \\
\hline P3 & 2409-3503, 1095 & 365 & $97.3,98.6$ & $84.7,92.6$ & $84.6,92.3$ & $99.4,99.7$ & $99.1,99.7$ & $96.3,97.8$ \\
\hline $6 \mathrm{~K} 1$ & 3504-3659, 156 & 52 & $97.4,100$ & $81.4,84.6$ & $82.1,86.5$ & $99.4,100$ & 100,100 & $98.1,98.1$ \\
\hline $\mathrm{Cl}$ & 3660-5561, 1902 & 634 & $97.3,99.1$ & $84.1,95.7$ & $84.1,95.7$ & $99.6,99.5$ & $99.3,99.5$ & $98.7,99.7$ \\
\hline $6 K 2$ & $5562-5717,156$ & 52 & $95.5,100$ & $82.1,90.4$ & $79.5,90.4$ & 100,100 & 100,100 & $99.4,98.1$ \\
\hline VPG & $5718-6281,564$ & 188 & $86.9,92.0$ & $97.0,99.5$ & $95.6,97.3$ & $98.9,99.5$ & $87.8,94.7$ & $97.9,99.5$ \\
\hline $\mathrm{Nla}$ & $6282-7013,732$ & 244 & $80.9,93.6$ & $99.3,98.2$ & $97.0,98.8$ & $99.2,98.8$ & $80.6,92.2$ & $99.0,99.2$ \\
\hline $\mathrm{Nlb}$ & 7014-8570, 1557 & 519 & $83.5,93.6$ & $98.8,99.0$ & $97.6,98.7$ & $98.7,98.7$ & $84.9,94.4$ & $98.2,99.0$ \\
\hline$C P$ & $8571-9371,801$ & 267 & $90.8,92.9$ & $97.5,98.9$ & $96.5,98.9$ & $99.4,98.9$ & $91.4,94.4$ & $91.6,94.0$ \\
\hline $3^{\prime}$ UTR & $9372-9702,331$ & - & $98.2,-$ & $84.0,-$ & $85.8,-$ & $99.1,-$ & $98.8,-$ & 99.1, - \\
\hline $\begin{array}{l}\text { Full } \\
\text { length }\end{array}$ & 1-9702, 9702 & 3061 & $87.9,92.8$ & $93.2,97.3$ & $90.9,95.9$ & $99.2,99.1$ & $94.1,97.4$ & $97.7,98.7$ \\
\hline
\end{tabular}

these isolates, and, moreover, to investigate whether the different RJ3 sites, namely different CP gene types, play a role in symptom induction in different plant species, tobacco (cv. 'Samsun'), potato (cv. 'Yukon Gold') and Physalis floridana plants were mechanically inoculated with $\mathrm{PVY}^{\mathrm{NTN}}-\mathrm{HN} 1, \mathrm{PVY}^{\mathrm{NTN}}-\mathrm{HN} 2, \mathrm{PVY}^{\mathrm{N}}-\mathrm{Jg}, \mathrm{PVY}^{\mathrm{O}}-\mathrm{RB}$, and $\mathrm{PVY}^{\mathrm{N}: \mathrm{O}}-\mathrm{Mb} 58$ as described previously [9]. Mock (buffer)-inoculated plants were used as a healthy control. As shown in Figure 1A, petiole and stem necrosis occurred on tobacco plants 15 days after inoculation with $\mathrm{PVY}^{\mathrm{N}}-\mathrm{Jg}, \quad \mathrm{PVY}^{\mathrm{N}: \mathrm{O}}-\mathrm{Mb} 58, \mathrm{PVY}^{\mathrm{NTN}}-\mathrm{HN} 1$ or $\mathrm{PVY}^{\mathrm{NTN}}-\mathrm{HN}-2$. Veinal necrosis also developed on these plants. On the other hand, the $\mathrm{PVY}^{\mathrm{O}}$-infected plants only developed mosaic symptoms on the leaves and were free of veinal, petiole and stem necrosis (Figure 1A). No symptoms were observed on the mock-inoculated plants. Various studies have indicated that HC-Pro plays an important role in necrosis development on tobacco plants $[5,21,22]$. All isolates but $\mathrm{PVY} \mathrm{O}^{\mathrm{O}}-\mathrm{RB}$ possessed a $\mathrm{PVY}^{\mathrm{N}}$-type of HC-Pro gene $[5,7,9,18]$ (Figure 1D), and therefore induced $\mathrm{PVY}^{\mathrm{N}}$-like symptoms including veinal/petiole/stem necrosis on tobacco plants. When inoculated to 'Yukon Gold' plantlets (5-leafstage), the isolates induced varied foliar symptoms including mild mottling $\left(\mathrm{PVY}^{\mathrm{N}}-\mathrm{Jg}\right)$, mosaic $\left(\mathrm{PVY}^{\mathrm{N}: \mathrm{O}}\right.$ $\mathrm{Mb} 58)$ and severe mosaic/stunting/leaf deformation (PVY ${ }^{\mathrm{O}}-\mathrm{RB}, \mathrm{PVY}^{\mathrm{NTN}}-\mathrm{HN} 1$ and $\mathrm{PVY}^{\mathrm{NTN}}-\mathrm{HN} 2$ ) (data not shown), consistent with the previous report [9]. No visible symptoms were observed on potato tubers produced from plants infected with $\mathrm{PVY}^{\mathrm{N}}-\mathrm{Jg}, \mathrm{PVY}^{\mathrm{O}}-\mathrm{RB}$ or $\mathrm{PVY}^{\mathrm{N}}$ : $\mathrm{O}-\mathrm{Mb} 58$; and in contrast, distinct necrotic ringspots were observed on potato tubers harvested from plants infected with PVY ${ }^{\mathrm{NTN}}-\mathrm{HN} 1$ or PVY ${ }^{\mathrm{NTN}}-\mathrm{HN} 2$ (Figure
1B), thus confirming that both types of recombinant $\mathrm{PVY}^{\mathrm{NTN}}$ isolates are capable of inducing PTNRD in sensitive potato cultivars.

It has been known that $\mathrm{PVY}^{\mathrm{O}}$ induces necrosis in Physalis floridana, whereas $\mathrm{PVY}^{\mathrm{N}}$ incites mottling in this species [1]. Using N/O hybrids comprised of the chimeric genome of $\mathrm{PVY}^{\mathrm{N}}-\mathrm{N} 605$ [23] and $\mathrm{PVY}{ }^{\mathrm{O}}$, the symptom formation on P. floridana due to PVY infection was mapped to the CP gene region [17]. Because of the varied genome compositions among the isolates (Figure $1 D)$, they could be used to investigate the putative role of genome segment(s) of PVY in symptom development on P. floridana, as done on tobacco [5,24]. Severe symptoms including leaf and stem necrosis, leaf-drop and stunting were observed on $P$. floridana plants infected with $\mathrm{PVY}{ }^{\mathrm{O}}-\mathrm{RB}, \mathrm{PVY}^{\mathrm{N}: \mathrm{O}}-\mathrm{Mb} 58$ and $\mathrm{PVY}^{\mathrm{NTN}}-\mathrm{HN} 2$ three weeks after inoculation (Figure $1 \mathrm{C}$ ), and as time progressed, the symptoms became more distinct. The isolate $\mathrm{PVY}^{\mathrm{N}: \mathrm{O}}-\mathrm{Mb} 58$ led to plant death five weeks after the inoculation. On the other hand, mild symptoms, mainly mottling, were observed on $\mathrm{PVY}^{\mathrm{N}}$-Jg and $\mathrm{PVY}^{\mathrm{NTN}}$-HN1 infected P. floridana plants (Figure $1 \mathrm{C}$ ). Taken together, it can be concluded that the CP gene originated from $\mathrm{PVY}^{\mathrm{O}}$ is likely responsible for the severe symptoms in $\mathrm{PVY}^{\mathrm{O}}-$, $\mathrm{PVY}^{\mathrm{N}: \mathrm{O}}$ - or $\mathrm{PVY}^{\mathrm{NTN}}-\mathrm{HN} 2$-infected $P$. floridana plants. These results, together with the results obtained using artificial PVY chimeras [17], demonstrate that the CP gene, especially the 5 ' proximal segment (nt 8572-9183) of the gene, plays a critical role in symptom formation in P. floridana upon PVY infection, and determines the pathoginicity of PVY isolates. The 3' proximal segment of NIb gene (nt 8136-8570) does not appear to be involved in the symptom 


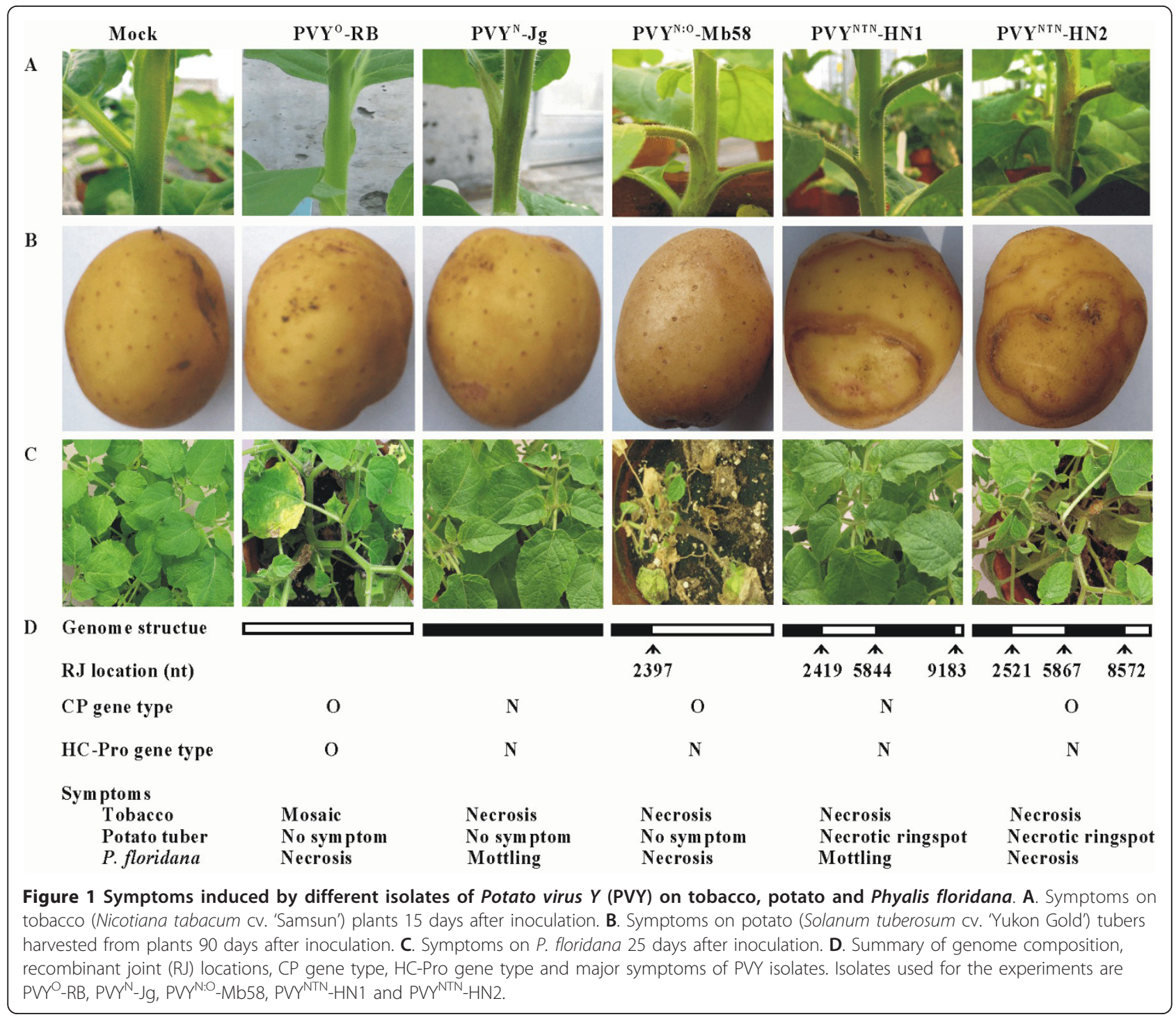

formation in P. floridana as suggested by Bukovinszki et al. [17]. It is also noteworthy that the different symptoms incited by different PVY types/isolates in tobacco, potato and P. floridana can be used to uncover the genome compositions of the virus.

\section{Acknowledgements}

The research was supported by the Ministry of Science and Technology of China under the project \# 20073346 to XX and CH and by Agriculture and Agri-Food Canada (AAFC) under the projects \#50 and \#1389 to XN. XH was a receipt of the Ministry of Education of China-AAFC Ph.D. Student Internship Program (2007-2008); XN is an adjunct professor at Hunan Agricultural University.

\section{Author details}

'Hunan Provincial Key Laboratory of Crop Germplasm Innovation and Utilization, Hunan Provincial Engineering Research Center for Potatoes, College of Horticulture and Landscape, Hunan Agricultural University, Changsha, Hunan 410128, China. ${ }^{2}$ Potato Research Centre, Agriculture and
Agri-Food Canada, P.O. Box 20280, 850 Lincoln Road, Fredericton, New Brunswick, E3B 4Z7, Canada.

\section{Authors' contributions}

$\mathrm{XH}$ carried out the experiments. XN designed, analyzed and wrote the paper. HC and XX collected isolates PVY ${ }^{\text {NTN }}{ }_{-H N}$ 1 and PVY ${ }^{N T N}-{ }_{-H N 2}$, participated in experiment planning and execution. All authors read and approved the final manuscript.

\section{Competing interests}

The authors declare that they have no competing interests.

Received: 22 November 2010 Accepted: 7 May 2011

Published: 7 May 2011

\section{References}

1. DD Shukla, CW Ward, AA Brunt, The Potyviridae. (Wallingford, Oxon, UK: CAB International, 1994)

2. JL Riechmann, S Laín, JA García, Highlights and prospects of potyvirus molecular biology. J Gen Virol. 73, 1-16 (1992). doi:10.1099/0022-1317-73-1-1

3. M Chrzanowska, New isolates of the necrotic strain of potato virus $Y\left(P V Y^{N}\right)$ found recently in Poland. Potato Res. 34, 178-182 (1991) 
4. L Glais, M Tribodet, C Kerlan, Genomic variability in Potato potyvirus Y (PVY): evidence that PVYN $Y^{N}$ and PVYNTN variants are single to multiple recombinants between $P Y^{O}$ and $P Y^{N}$ isolates. Arch Virol. 147, 363-378 (2002). doi:10.1007/s705-002-8325-0

5. $X$ Nie, RP Singh, M Singh, Molecular and pathological characterization of $\mathrm{N}$ : $\mathrm{O}$ isolates of the Potato virus Y from Manitoba, Canada. Can J Plant Pathol. 26, 573-583 (2004). doi:10.1080/07060660409507178

6. M Le Romancer, C Kerlan, M Nedellec, Biological characterization of various geographical isolates of potato virus $Y$ inducing superficial necrosis on potato tubers. Plant Pathol. 43, 138-144 (1994). doi:10.1111/j.13653059.1994.tb00563.x

7. X Nie, RP Singh, Evolution of North American PVY ${ }^{\text {NTN }}$ strain Tu 660 from local PVY ${ }^{N}$ by mutation rather than recombination. Virus Genes. 26, 39-47 (2003). doi:10.1023/A:1022326021195

8. RP Singh, DL McLaren, $X$ Nie, M Singh, Possible escape of a recombinant isolate of Potato virus $Y$ by serological indexing and methods of its detection. Plant Dis. 87, 679-685 (2003). doi:10.1094/PDIS.2003.87.6.679

9. $X \mathrm{Hu}, \mathrm{C} \mathrm{He}, \mathrm{Y}$ Xiao, $X$ Xiong, $X$ Nie, Molecular characterization and detection of recombinant isolates of Potato virus $Y$ from China. Arch Virol. 154, 1303-1312 (2009). doi:10.1007/s00705-009-0448-z

10. $\vee$ Thole, T Dalmay, J Burgyan, E Balazs, Cloning and sequencing of potato virus Y (Hungarian isolate) genomic RNA. Gene. 123, 149-156 (1993). doi:10.1016/0378-1119(93)90118-M

11. $X$ Nie, RP Singh, Probable geographical grouping of PVYN and PVYNTN based on sequence variation in P1 and 5'-UTR of PVY genome and methods for differentiating North American PVY ${ }^{\text {NTN }}$. J Virol Methods. 103, 145-156 (2002). doi:10.1016/S0166-0934(02)00023-X

12. $X$ Nie, RP Singh, A new approach for the simultaneous differentiation of biological and geographical strains of Potato virus $Y$ by uniplex and multiplex RT-PCR. J Virol Methods. 104, 41-54 (2002). doi:10.1016/S01660934(02)00037-X

13. $X$ Nie, RP Singh, Specific differentiation of recombinant $P V Y^{N: O}$ and $P V Y^{N T N}$ strains by multiplex RT-PCR. J Virol Methods. 113, 69-77 (2003). doi:10.1016/ S0166-0934(03)00221-0

14. LM Piche, RP Singh, $X$ Nie, NC Gudmestad, Diversity among Potato virus $Y$ isolates obtained from potatoes grown in the United States. Phytopathology. 94, 1368-1375 (2004). doi:10.1094/PHYTO.2004.94.12.1368

15. M Chikh Ali, T Maoka, KT Natsuaki, The occurrence and characterization of new recombinant isolates of PVY displaying shared properties of PVY ${ }^{N W}$ and PVYNTN J J Phytopath 155, 409-415 (2007). 2007. doi:10.1111/j.14390434.2007.01251.x

16. M Chikh Ali, T Maokac, T Natsuakib, KT Natsuaki, PVY NTN-NW, a novel recombinant strain of Potato virus $Y$ predominating in potato fields in Syria. Plant Pathol. 59, 31-41 (2010). doi:10.1111/j.1365-3059.2009.02174.x

17. A Bukovinszki, R Gotz, E Johansen, E Maiss, E Balazs, The role of the coat protein region in symptom formation on Physalis floridana varies between PVY strains. Virus Res. 127, 122-125 (2007). doi:10.1016/j.virusres.2007.03.023

18. B Nie, M Singh, A Sullivan, RP Singh, C Xie, X Nie, Recognition and molecular discrimination of severe and mild $P V Y^{O}$ variants of Potato virus $Y$ in potatoes in New Brunswick, Canada. Plant Dis. 95, 113-119 (2011). doi:10.1094/PDIS-04-10-0257

19. MA Larkin, G Blackshields, NP Brown, R Chenna, PA McGettigan, H McWilliam, F Valentin, IM Wallace, A Wilm, R Lopez, JD Thompson, TJ Gibson, DG Higgins, ClustalW and ClustalX version 2. Bioinformatics. 23 2947-2948 (2007). doi:10.1093/bioinformatics/btm404

20. KS Lole, RC Bollinger, RS Paranjape, D Gadkari, SS Kulkarni, NG Novak, R Ingersoll, HW Sheppard, SC Ray, Full-length human immunodeficiency virus type 1 genomes from subtype C-infected seroconverters in India, with evidence of intersubtype recombination. J Virol. 73, 152-160 (1999)

21. M Tribodet, L Glais, C Kerlan, E Jacquot, Characterization of Potato virus $Y$ (PVY) molecular determinants involved in the vein necrosis symptom induced by PVYN isolates in infected Nicotiana tabacum cV. Xanthi. J Gen Virol. 86, 2101-2105 (2005). doi:10.1099/vir.0.80926-0

22. $X$ Hu, T Meacham, L Ewing, SM Gray, AV Karasev, A novel recombinant strain of Potato virus $Y$ suggests a new viral genetic determinant of vein necrosis in tobacco. Virus Res. 143, 68-76 (2009). doi:10.1016/j. virusres.2009.03.008

23. G Jakab, E Droz, G Brigneti, D Baulcombe, P Malnoe, Infectious in vivo and in vitro transcripts from a full-length CDNA clone of PVY-N605, a Swiss necrotic isolate of potato virus Y. J Gen Virol. 78, 3141-3145 (1997)
24. V Ramírez-Rodríguez, K Aviña-Padilla, G Frías-Treviño, L Silva-Rosales, J Martínez-Soriano, Presence of necrotic strains of Potato virus $Y$ in Mexican potatoes. Virology J. 6, 48 (2009). doi:10.1186/1743-422X-6-48

doi:10.1186/1743-422X-8-207

Cite this article as: Hu et al:: Differential pathogenicity of two different recombinant PVYNTN isolates in Physalis floridana is likely determined by the coat protein gene. Virology Journal 2011 8:207.

\section{Submit your next manuscript to BioMed Central and take full advantage of:}

- Convenient online submission

- Thorough peer review

- No space constraints or color figure charges

- Immediate publication on acceptance

- Inclusion in PubMed, CAS, Scopus and Google Scholar

- Research which is freely available for redistribution

Submit your manuscript at www.biomedcentral.com/submit
C) Biomed Central 